\title{
A policy on the move? Spatial planning and State Actors in the post-devolutionary UK and Ireland
}

\author{
BEN CLIFFORD AND JANICE MORPHET \\ Bartlett School of Planning, University College London, Wates House, 22 Gordon Street, London \\ WC1H OQB \\ E-mail: ben.clifford@ucl.ac.uk; j.morphet@ucl.ac.uk \\ This paper was accepted for publication in November 2013
}

\begin{abstract}
Devolution has led to a dramatic restructuring of the UK state over the last 15 years. Planning is a devolved function and a concerted process of 'planning reform' has been implemented by devolved (and central) government since devolution, including a move from 'land-use' to 'spatial planning'. Despite some expectations of, and pressure for, policy divergence post devolution, we draw on findings of discourse analysis to demonstrate how there are common framings and understandings of the concept of 'spatial planning' present in the policy documents of all the UK administrations, and in Ireland. As such, we conceptualise spatial planning as what, after Peck and Theodore (2010, Geoforum 41 169-74), we might consider a 'policy on the move'. Policy mobility is a fundamentally geographical phenomenon and its presence here raises questions about the mechanisms by which spatial planning has been mobilised. Drawing on interview data, we highlight the role of civil servants who meet through the British-Irish Council's workstream on spatial planning and a forum known as the 'Five Administrations' meetings. The relational connections between these state actors suggest that they are key 'transfer agents' and their role helps explain some of the path dependency in planning reform post devolution.
\end{abstract}

KEY WORDS: devolution, United Kingdom, spatial planning, state personnel, British-Irish Council, interviews

\section{Planning in an age of devolution}

A Ithough nearly 15 years old, UK devolution continues to evolve and mutate; Shaw and MacKinnon (2011; drawing on Goodwin et al. 2005) highlight the ongoing processes of 'filling in' seen in the devolved territories, with 'structural filling in' referring to the establishment of new, and reconfiguration of existing, organisational forms, and 'relational filling in' involving how these organisations operate in terms of using their powers and developing links with other organisations and actors. Through an understanding of the state as a 'peopled organisation' (Peck 2001, 451), a number of scholars suggest that state actors are playing a key role in this filling in: 'Devolution is shaped by, and also shapes, the action and strategies of a variety of state personnel' who have a significant role in 'actively producing the United Kingdom's new territories and scales of governance' (Jones et al. 2004, 89). Despite a plethora of scholarship on devolution, important questions remain about the nature of policy development in the post-devolutionary UK, and relations between policymakers across these administrations.

An interesting lens through which to examine and understand these processes is in relation to planning. Devolution has the potential to heavily impact town and country planning, which is devolved to Wales, Scotland and Northern Ireland'. The last decade has seen a concerted process of 'planning reform' implemented by central and devolved government across the UK, with an agenda to modernise the planning system in relation to a number of different objectives (Clifford and Tewdwr-Jones 2013). This reform has centred on the transition from a 'land-use' to a 'spatial planning' approach (Morphet 2010). Spatial planning attempts to take a wider role than traditional land-use planning by integrating policies for the development and use of land with other policies and programmes which influence the nature and function of places, with a concern for delivery on the ground. These trends can also be seen in Ireland, which although an independent nation-state, is described as having a 'British style' planning system 
compared with differing continental approaches (Newman and Thornley 1996).

It is noticeable, although little commented on, that civil servants involved in policymaking related to planning have two forums which bring them together: the so-called 'Five Admins [administrations]' meetings of Chief Planners (the senior officials responsible for planning in the UK, Irish, Northern Irish, Scottish and Welsh governments) and the 'Spatial Planning' workstream of the British-Irish Council (BIC). In this paper, we draw on empirical work to illustrate the interconnectedness of officials, and the role of these forums in policymaking and mobility in the devolved UK and Ireland. In doing so, we aim to develop our understanding both of the political geographies of devolution generally as well as the implementation of spatial planning and planning reform specifically. We begin by considering existing work on devolution and policy sharing.

\section{The devolution context}

A particular focus for existing work on devolution, including that by planning scholars, has been the degree of policy divergence between the new administrations and the UK government. Although planning was the responsibility of the territorial departments of state pre devolution (the Northern Irish, Scottish and Welsh Offices), it is widely argued they did little policymaking and focused on implementing Whitehall-driven agendas ${ }^{2}$. With the advent of devolution under the New Labour administration there were a number of predictions of policy divergence in planning (Tewdwr-Jones 1999; Allmendinger 2002), reflecting perceived pressures for the newly devolved territories to establish distinctive and more culturally aligned policies (Hazell 2000). In the early years of devolution, this expected policy divergence in planning did not materialise. Despite some differences in the minutiae of planning systems and instruments, similar reform agendas were followed across the UK (Hayton 2002). This continues to be the case. This lack of greater policy divergence in planning reflects the situation across a number of policy spheres (Birrell 2012). Nevertheless, the dynamics of policymaking and policy ownership have changed post devolution, and it is noticeable that there is little written about how policies are actually shared and move between territories and administrations post devolution.

As well as policy divergence, another key concern for scholars of UK devolution has been the weakness of interterritorial arrangements. There has been a tendency to rely on collegiality and goodwill and it is noticeable that formal mechanisms for intergovernmental relations post devolution have hardly been used, except to define negotiating lines for European Union matters (McEwen et al. 2012). The role of the civil service has been highlighted, as 'a repository of common values and shared understandings of 'how to do things', easing a process of information coordination of problematic issues by officials' (Jeffrey and Wincott 2006, 9; see also Parry 2012). This is suggestive of the role of state actors central government civil servants - in shaping the new institutions created by devolution.

This role is further suggested by work from several Geographers examining devolution. Jones et al. (2004) argue it is important to explore the working practices and institutional cultures and identities of state personnel to fully understand devolution, and MacKinnon and Shaw $(2010,1227)$ suggest the need to consider 'the political agency and struggles that shape geographies of governance under devolution'. Drawing on Painter (2008), Goodwin (2013, 1188) argues that the new spaces of devolution are the product of 'networked flows and relational processes'. In this paper, we explore these processes with respect to flows of policy around spatial planning and relations between civil servants responsible for planning policy in their administrations.

\section{The policy context}

Devolution is a legal principle allocating central powers to lower levels of governance representing specific territories within the state to share decisionmaking for that space. Questions about policy relationships between the existing and new state spaces thus arise, and this raises the spectre of the movement of policy between these spaces. 'Policy transfer' is a well developed body of work which refers to the broad 'process by which knowledge (of ideas, institutions, policies and progams [sic]) in one political system is fed into the policymaking arena (in the development and change of policies, programs and institutions) in another political system' (Dolowitz 2001, 374). There are different forms and degrees of transfer, which can range from copying to emulation to inspiration (Dolowitz and Marsh 2000). Stone (2004) talks of the 'soft transfer' of broad policy ideas and norms and the 'hard transfer' of policy practices, structures, tools and instruments.

Recent discussions in Geography around 'policy mobilities' have developed this work on policy transfer. It is argued that we should use the language of mobility 'rather' than 'transfer' (Peck and Theodore 2010): a discursive shift to signify that policies do not usually travel as 'packages' but as bits and pieces which are then assembled in particular ways, in particular places, for particular purposes (McCann and Ward 2012a). In the mainstream 'policy transfer' literature the focus has been on the national scale, with a tendency to conceptualise producer innovators and consumer emulators engaged in rational transactions, when we need instead to understand policy formation and transformation as socially 
constructed processes (Peck and Theodore 2010; cf. Dolowitz and Marsh 2012).

It is vital to consider the institutional geography of the sites and scales through which policies move and to interrogate the 'multiple and overlapping spaces of policy making' (Cochrane and Ward 2012, 5). The flows of policies, policy models, and policy knowledge via key communities, networks, institutions, infrastructure and places and their assemblage is a central concern. As McCann argues:

The circulation of policy knowledge is paradoxically structured by embedded institutional legacies and imperatives (e.g. by longstanding policy paradigms, path dependencies, ideologies, and frames of reference or by external forces, like political-economic restructuring, which often necessitate the easiest, fastest, and most politically feasible transfers).

McCann (2011, 109)

Questions must be raised about why some policies are anointed as favoured 'models', how the chosen models help consolidate norms and paradigms, how models are mobilised, and how they are changed along the way (McCann and Ward 2012b).

Central to these policy mobilities is the role of 'transfer agents' (Stone 2004). Given the fundamentally social nature of policymaking, studies of policy mobilities must consider the role of the everyday activities of transfer agents in the travels of policy, such as their use of technologies, interpersonal connections, travels and attendance, at meetings (Stone 2004; McCann 2011). Policy actors are not, however, lone learners but embodied members of epistemic, expert and practice communities; knowledge actors located in organisational and political fields, with identities and professional trajectories linked to the fixes they promote. Transnational policy communities of experts may arise 'and form common patterns of understanding regarding policy through their regular interactions' which become a form of shared policy learning (Stone 2001, 7) and then help policy ideas spread and take root. Shared understandings develop through meetings and documents (Freeman 2012) so that 'policy mobilities are simultaneously fixed in and mobilized through communities of social actors and their associated institutions' (McCann 2011, 114).

State actors have an important role to play in the production of the new state spaces post devolution, and there are important questions as to how they help the flow of policy between these spaces. Drawing on this conceptual material, in the following section we consider spatial planning as a 'policy on the move' before then interrogating the role of civil servants as transfer agents assisting the flow of ideas and instruments related to spatial planning.

\section{Spatial planning on the move}

Since the millennium there has been a concerted effort to introduce a shift from a so-called 'land-use' to a 'spatial' planning approach in UK practice. This is about trying to be more integrated, focused on delivery and sustainability, and concerned not just with land-use control but also the coordination of all policies and programmes related to 'place-making'. Whilst Nadin (2007) sees spatial planning as a new approach more embedded in the apparatus of governance, there has been some debate as to how distinctive 'spatial planning' is when set against the long history of planning practice (for example, Taylor 2010). Whilst we would agree with Nadin more than Taylor, what is most relevant here is simply the fact that 'spatial planning' has been the framing device for concerted processes of planning reform occurring in the UK and Ireland in recent years. Despite some difficulties implementing these reforms (Clifford 2013), in less than 10 years 'spatial planning' became the organising discourse framing UK planning; a new 'planning orthodoxy' (Vigar 2009) with echoes of European practice (Tewdwr-Jones 2012).

During the period since devolution, spatial planning has been introduced and refined in all national planning systems in the UK and in Ireland (the term has not been used by the Scottish government but its reforms have used similar instruments and devices to those described as 'spatial planning' elsewhere). Indeed one feature of the introduction of the concept has been the frequency with which it has been updated and amended. To examine the mobility of 'spatial planning' between these administrations further, a discourse analysis of the various planning policy and consultation documents published by central and devolved governments in the UK and Ireland from 2000 to 2012 was conducted. This approach was selected as it is now considered a critical method in assisting in the understanding the processes of institutional change (Schmidt 2010; Panizza and Miorelli 2013) and thus relevant given our focus on changing institutional relationships post devolution. The analysis was conducted through a careful reading of each document to examine the way 'spatial planning' was defined, used as a general organising concept, to consider the similarity of policy proposals, and to identify cross references to practice elsewhere.

Looking at this corpus of documents, a common code can be seen with respect to the way spatial planning is imagined and applied through scales and processes. Clear patterns can be traced when looking at spatial planning discourse, policy instruments and practices: particular initiatives associated with this shift from land use to spatial planning which have occurred in one nation can quickly be seen being adopted, in adapted form, in some or all of the others. 
A shared language emerges slowly through successive published documents and, whilst there have been numerous changes overall, spatial planning is presented specifically as a 'new' concept (e.g. CLG 2007 a 31 ). It is noticeable that there is a tendency for government documents to cross reference similar planning shifts in other parts of the UK or Ireland, for example spatial planning is introduced with reference to the 'modernisation in land use planning in England and Wales, Scotland and Ireland' in the document Planning reform in Northern Ireland (Lloyd 2008, 3). Similarly, there are currently moves to introduce city regions into Welsh policy, with explicit reference to Scotland: 'We recommend an over-arching city region strategic planning tier. ... This should provide a clear hierarchy of decision-making as in Scotland' (Welsh Government 2012, 8). As a specific example, at the level of terminology, we can observe this with the shift from the use of the term 'development control' to 'development management'. Looking at official government planning publications, in Scotland, the emergence of the use of 'development management' seems to have been in 2005 (cf. Scottish Executive 2004a 2005). In Ireland, it is around 2006-7 (cf. ECLG 2005 2007). In England, about 2007 (cf. CLG 2006 2007b). In Northern Ireland the shift is about 2007-8 (cf. DoENI 2006 2008) and in Wales around 2009 (WAG 2009). This is only a very narrow example, but is suggestive of flows of discourse between the policymakers of each administration.

A much broader example is the idea of a 'National Spatial Plan'. The development of an integrated spatial strategy for Northern Ireland, Shaping our future, published in 2002 (DRD 2002), created a new model for spatial planning in the UK. It sought not only to provide a spatial vision and priorities but also to consider infrastructure and investment decisions that need to accompany the achievement of this vision. In Ireland, the National spatial strategy (TSO 2002) also adopted the same language of gateways, hubs, spatial analysis by functional rather than administrative areas, and the plan also identifies key infrastructure. This idea was influential in Wales, with the development of the Wales spatial plan (WAG 2004) and in Scotland, with the development of the National planning framework for Scotland (Scottish Executive 2004b). The Welsh plan was a statutory document from the start; the Scottish document was not, but became so in 2006, following the perceived success of the Welsh model (Scottish Government 2008). We can even see the adoption of an integrated approach to infrastructure and land use in the crown dependencies, for example Guernsey's recent States strategic plan (States of Guernsey 2012). That said, there is currently no English or indeed UK national spatial strategy (TCPA 2010).

Drawing on the ideas of policy mobility, it seems spatial planning has certainly been a 'hot' policy idea and has been constructed as a model of best practice which has become mobile with flows of ideas, language and policy instruments around the administrations of the UK and Ireland. For policy mobility, there must be transfer agents. Undoubtedly the work of a range of knowledge actors has helped mobilise spatial planning [Allmendinger (2011) particularly mentions planning academics] but we believe civil servants working in the sections of government responsible for planning policy have played a vital, and previously under-appreciated, role.

\section{State actors mobilising spatial planning}

\section{The 'Five Admins' and the BIC}

Two specific forums exist to enable civil servants involved in planning policymaking from administrations across the UK and Ireland to come together and, we would argue, act as policy communities where individual members subsequently act as transfer agents back into their own institutional settings. The first is the 'Five Admins' meetings. These are meetings of the 'Chief Planners' in each nation's government departments responsible for planning. Although there is some uncertainty amongst participants as to the origins of the group, it is believed the meetings were established by officials from the then Scottish Executive soon after devolution and includes representatives from the relevant UK, Scottish, Welsh, Northern Irish and Irish government departments. These meetings were established by officials, for officials, and are not part of a wider politically driven network (and there is very little publically available information about the group).

The second forum is a 'workstream' of the BIC. The BIC was set up under the Good Friday Agreement in 1998 as a means of maintaining relationships between national states as devolution progressed, particularly in the context of the political settlement in Northern Ireland, and was reinforced by the St Andrews Agreement in 2007. Its membership comprises representatives from the governments of Ireland and the UK, the devolved authorities in Northern Ireland, Scotland and Wales, and the crown dependencies of Guernsey, the Isle of Man and Jersey. The purpose of the Council is to:

Promote the harmonious and mutually beneficial development of the totality of relationships among the peoples of these islands...the BIC will exchange information, discuss, consult and use best endeavours to reach agreement on co-operation on matters of mutual interest.

BIC (2013, online)

The BIC's work is centred on several workstreams established by Ministers. The 'Collaborative Spatial Planning' workstream held an inaugural meeting in Belfast in June 2009 and brings together officials 
responsible for regional development strategies, national planning strategies and frameworks from each member administration.

Both forums follow a similar format, with officials meeting every six months, the meetings rotating between the administrations and the meetings, including updates on each administration's current policy developments, then a more detailed discussion around particular topics. The Five Admins meetings also include site visits to see exemplar planning delivery on the ground. The BIC workstream meetings are attended by civil servants, but the chairing official then attends meetings with other workstream chairs and Ministerial summits, whereas one interviewee told us, the Five Admins 'operates at a strategic level with no formal role. Things identified at the meetings may come through formal routes later'.

We interviewed 17 civil servants who attend or have attended the two groups, using semi-structured interviews which included questions on their experience of working together, the nature of policy discussions within and between the meetings, and their view of the professional relationships between them as a group of colleagues. These interviews were then transcribed and coded by annotating the transcript with descriptive, interpretive tags to help identify categories and patterns. Recurring themes were then identified and illustrative quotations selected. We also observed one meeting of the BIC workstream. In the following subsections we explore the interactions through these forums.

\section{'Mundane practices' which oil the policy machine}

There was a very real sense that the officials attending the meetings valued these opportunities to share and learn from each other about policy developments in their respective territories. The groups are used to compare best practice and to 'build a shared understanding' (Interviewee 1). This is significant as a shared understanding over concepts like 'spatial planning' is a catalyst for their mobility. The emphasis on keeping track of policy developments in each other's territories was valued partly due to personal professional interest, partly because new developments might be a source of policy inspiration or reinforcement for use back home, and partly because the interconnections in media, public and polity between the administrations meant that if something particularly significant was happening in one territory, the civil servants in the others would probably need to prepare 'lines to respond'. There was a collegiality in the meetings where updates would often be 'early warnings, we're going to do this, you might have questions' (Interviewee 2).

The meetings were important as the site for these exchanges partly because it was useful to have something that forced participants to be periodically made aware of developments in each other's territories, but especially because the meeting opened up the opportunity for a full discussion in a space protected by 'Chatham House rules':

I do find it very useful to get a flavour for you know how their thinking evolves ... also it's quite nice to hear about the sort of political hilarities. We are all civil servants obviously following political direction and how that plays out can sometimes be quite interesting and of course when you speak, talk face-to-face, people can be more frank about that.

Interviewee 2

This was interesting because, as Evans (2009) states, policymakers now have an increased ability to access knowledge of policy initiatives internationally via the internet. Many of the interviewees admitted to using the internet to find out more about policies in other territories, yet felt such 'policy tourism' could not just be done virtually:

You can quite easily Google and identify lots of international best practice but it's the context ... that makes the difference. If you didn't have the meeting ... you'd be missing an understanding of the issue.

Interviewee 3

Thus it is the meetings themselves - because of the richness of information available compared with other channels - which are favoured sites for policy exchange.

The meetings were also valued for the opportunities to make and maintain interpersonal connections with equivalents performing similar roles in the different territories:

You know, these soft elements are easily under-rated, in the sort of just making connections, knowing who to go to, who to call-up when you have another issue ... to make and maintain contacts in other administrations, to keep dialogue going.

Interviewee 2

It was noticeable in the meeting we observed that there was not just business talk in the formal meeting but also small talk over sandwiches, helping maintain personal connections. These strong personal contacts were what Urry (2004; in McCann 2011) characterises as 'connections at a distance', maintained by intermittent face-to-face conversations. They provided actors the opportunity to know who to contact to find out more about particular policies between meetings, the chance to better coordinate between jurisdictions when required, and also something of a therapeutic experience:

There is a mixture of professional development and an opportunity to just have frank discussions with each other ... if they didn't exist I would be looking for an 
opportunity to meet my equivalents and be able to talk about the challenges of delivering in the post.

Interviewee 4

This highlights how the sharing of everyday experience with trusted interpersonal contacts can help the movement of practice.

For some of the smaller administrations, the meetings provided access to a wider policy community and thus source for policy ideas, evidence and expertise. Interviewee 5, a civil servant from a devolved territory, said 'Even in these times of austerity, the scale of resources in London compared to the rest of us is unbelievable'. This appeared to be primarily about the number of staff working in a particular field, and so the ability to maintain expertise. Similarly Interviewee 6, from one of the Crown Dependencies, said the BIC workstream meetings were really valued 'because coming from a small island and having contact with, with the sort of civil servants I wouldn't normally come across at all, is quite an opportunity'. The meetings allowed the chance to 'spark off ideas' and find opportunities for collaboration which might otherwise be missed. There were clear examples given to suggest that sometimes the newly devolved territories could not match the institutional capacity of the nation-state governments, as Keating (2009) suggests, hence driving more cooperative policy making through these forums and networks. Yet there was some reciprocity in that the representative of the UK government on the BIC workstream found the contacts made at the meeting just as useful as the smaller administrations, particularly because the group assisted him in developing common lines on EU matters, such as territorial cohesion where the UK government represented all the administrations.

\section{Policy mobility in practice}

Many of the civil servants interviewed were quite happy to give examples of the ways in which policy had been shared between the administrations of the UK and Ireland through and beyond the meetings. Sometimes this was as a result of examples of 'best practice' from one administration discussed at the meeting being emulated by others, for example around renewable energy, flood assessment, e-planning, Environmental Impact Assessment or the Community Infrastructure Levy. As Interviewee 7 commented about the meetings, 'you're just looking to pick up ideas as much as anything'. Sometimes it was through the meetings fostering the joint commissioning of work and expertise, for example from consultants around new European requirements for 'Territorial Impact Assessments'. On other occasions it seemed to involve civil servants from one territory acting as an advisor to another; direct examples were given of the former Chief Planner of
Scotland advising the Irish and Northern Irish governments and of civil servants from England assisting with 'Examinations in Public' being held on the Channel Islands ${ }^{3}$.

Officials from some of the smaller island administrations also readily admitted that on occasion they had copied policies from elsewhere due to the very limited policymaking capacity their administrations possessed: 'We needed to update the law, so we basically lifted quite a lot of the English legislation' (Interviewee 7). Yet even in cases of copying, the sense of policy ownership remained important: 'We can look at what's going with the UK ... and we've got the ability here to kind of tweak it to our needs' (Interviewee 8). It was also not just actors from the tiny island administrations behaving in this way. Interviewee 9, a civil servant from a devolved administration gave an example of a time she had used a report on planning reform in England as direct inspiration to suggest some 'quick win' reforms to the planning system in her territory at the request of her Minister, bringing to mind Stone's (1999, 55) description of 'time-strapped politicians and bureaucrats'. However, a number of interviewees were keen to stress it was not just the case of devolved administrations emulating policy from London, a point we return to below.

Finally, there was policy mobility around negative experiences as well as positive ones [in accordance with Dolowitz and Marsh's (2000) 'negative inferences']. Interviewee 10 explained that they would often look at policies from the other territories, but with time taken to see how the policy development panned out before trying to apply it themselves:

There's a saying here, why reinvent the wheel, if you can take the legislation developed elsewhere, look at it and see particularly if it's been in operation for a short while, see the reaction to it.

Similarly examples given were a participant who would update the meeting that a policy had not been particularly successful and the others would be 'warned off it'. Interviewee 11 also explained how sometimes you might see a good policy but not be in a position to emulate or implement it in your own territory due to other factors, such as political constraints. The state actors in these two forums can therefore be seen acting together to both engender but also to occasionally inhibit policy mobility through their sharing of their experiences of policy development and delivery in practice.

\section{Geographical imaginations}

It was clear that a sense of geography amongst our interviewees and other members of the polity in their territories was influencing policy mobility, but this was in complex ways. For some actors, there was talk 
of differences between the devolved territories and England. Interviewee 12 commented that 'everyone is seeking economic growth but in [his territory] planning is seen as part of the solution whereas in England it was seen as part of the problem'. This was apparently in reaction to the negative discourse from several UK politicians about planning being an obstacle to economic growth, including the Prime Minister calling planners the 'enemies of enterprise' (Hickey 2011), which has not been seen from politicians in the devolved nations. Interviewee 12 also felt the interactions about 'spatial planning' at the BIC meetings worked best for some actors:

I think it probably works best for, if you like, the Celtic fringe administrations, it works best for Scotland, Irish administrations and Wales because we're all of similar scale. We've got similar territorial characteristics and we're, you know, facing common challenges.

Other actors mentioned how each of these administrations had national spatial strategies but England did not. There was a sense that the Celtic nations might be progressing along a similar path in planning reform, as in some other policy areas (Danson et al. 2012).

Yet the policy relationships are complex. In the discourse analysis and interviews, England was often defined as the 'other' against which devolved and island politicians wished to differentiate themselves, but there was also a sense that, through shared media and professional links, reforms in England would heavily impact the others:

There's inevitably, for, if there's something big happening in England there is overspill into, into Scotland, Wales and Northern Ireland.

Interviewee 12

Keating (2012) highlights how there are policy 'spillover' effects from one part of UK to other, and Jeffrey and Wincott (2006) suggested that these might particularly be from UK government decisions for England to the devolved administrations, but we found little evidence of this. There was some discussion that media coverage led to pressure to respond to English policies - localism was used as a particular example several times - but there was also discussion of the way post-devolution there was a real sense of greater local policy-making and responsibility. Interviewee 11 commented:

I think it's inevitable that there's some cross pollination but I wouldn't necessarily take the line that it's all one way... England is not always regarded as the administration to follow and in some respects the devolved administrations have been equally if not more adventurous with some of the changes put forward.
This is suggestive that flows of policy post devolution are multi-directional rather than from one single 'centre'.

Indeed, there was a feeling that there was a more mutually respectful and trusting relationship between policymakers post devolution. Furthermore, Interviewee 12 commented that differences between the administrations were frequently over-stated:

At an official level . . . relationships are extremely cordial despite all the sort of the high level political drama which is partly for media public consumption.

Interviewee 3 offered the example of how they often found it easy to agree common positions for European matters as they were 'all on the same page'. This commonality of all administrations, including the UK government, was brought into perspective when comparisons were made or invited with other European nations. There was discussion of similar systems of common law and land-use patterns, so 'our first steps when we were looking at policy was to say actually what's the equivalent in [the other parts of the UK and Ireland]' (Interviewee 1). This was driven not just by a sense of similarity but also by barriers to policy learning elsewhere, not least language. Such practicalities mean that policy tourism, even in an age of the internet, is probably more likely to involve short breaks to repeat destinations rather than long-haul globetrotting.

Despite any differences between administrations, that planning is a professional field with which all the participants in the meetings were intimately involved fostered a sense of common value between them. Some of this is, as Interviewee 12 suggested, was down to the common professional training and history of being in a more united nation-state:

There has been increasing divergence between the various systems but they're all in, grounded in I suppose the UK planning philosophy which emerged in the interwar period so they're all, you know, quite distinct from European practice.

A shared cultural legacy seems to be an important consideration in the operation of these forums and the similarity of origins may therefore lead to the other UK nations being seen as the most appropriate models for potential planning reforms. Furthermore, Berry and Berry (1999; in Stone 2004) suggest the presence of a professional (or epistemic) community can make some bureaucrats more attuned to policy transfer. This is seen in planning.

Overall, there was a strong sense of the administrations being inter-dependent, that members of the forums had common values, and faced similar issues albeit sometimes in different political contexts. As Interviewee 9 commented about policymaking around spatial planning: 
It's a generic discipline, we all have to implement the same EU directives, and generally we do all genuinely want place-shaping and delivery on the ground.

The result was a high degree of policy mobility between the administrations.

\section{Conclusion}

It is clear that the early predictions of UK devolution leading to widespread policy divergence in planning have not materialised. Whilst there has been some spatial differentiation post devolution, this has not been divergent or led to fragmentation. Common practices of governance and delivery have emerged and spatial planning represents a policy fugue where similar themes and models are developed and delivered in culturally determined ways within each territory. Spatial planning has been introduced into UK and Irish planning practice at different times and in different ways but the resulting systems now operate very similarly, particularly in terms of their effective outcomes. Spatial planning has very much been a 'hot' policy idea over the last decade, with considerable policy mobility, but with the precise components assembled within each of the newly devolved territories, and indeed helping make those territories. It was quickly anointed as a favoured model which has helped consolidate the norms of reform and the paradigm of planning under neoliberal governance.

That there are similar themes in planning reform in each of the territories of the UK and in Ireland, and the manner in which particular ideas about a new 'spatial' approach can be traced in one territory and then appearing in another sometime afterwards, suggests devolution has created new spaces for policy experimentation and mobility. Stone (2004, 552) argues 'transfer is more likely to occur when lessons are 'proximate'; that is, transferred from a jurisdiction that is geographically, ideologically or culturally proximate' and this can certainly be seen between the devolved territories of the UK.

This lack of divergence, despite some important drivers for distinctive policies and the desire of the newly devolved administrations to make their mark on policy development, can certainly be linked to some strong structural drivers. Considerable political and policy interdependence remains after devolution and the role of European policy is particularly important here (Morphet 2013). However, structural drivers are only part of the picture. Indeed, it is noticeable that a number of commentators highlighted the commonality of the Labour Party being in power as a reason for the lack of divergence in the early years of devolution, yet there has been little radical policy divergence since this stopped being the case. And whilst legacies from the predevolution state are undoubtedly important, it is also noticeable how there has been policy mobility between the UK and Ireland around spatial planning despite the statutory planning system emerging after Irish independence.

An important part of the explanation for this is the role of state actors operating as a policy community and individually as 'transfer agents'. Civil servants, sharing a common 'governing code' (Bradbury 2006) and influenced by the inherited routines and norms of the civil service culture as well as the professional context of planning, meet in person every six months through two forums and maintain interpersonal contacts. The result is a web of connections that assists the mobility of policy. The important periodic co-presence of these actors in specific places allows them to develop a community and to consider, compare and contrast different policy initiatives and delivery methods. The meetings of the BIC Spatial Planning workstream and Five Admins are thus a key part of the institutional geography of policy mobility in the post-devolutionary UK and Ireland. These state actors are not entirely free agents, and certainly the way spatial planning policies have been assembled in each territory is influenced by a range of factors including, of course, the role of politicians, but they have played a key role in making spatial planning a 'mobile' policy. Such linkages through officials may be 'intransparent' (Jeffrey 2009) but they give civil servants access to wider policy communities and are indicative of the reliance on 'relational filling in' associated with UK devolution as well as illustrative of the social nature of policy mobility. This is likely to lead to a certain path dependency in ongoing state modernisation so that we will continue to see similarity in planning reforms across these isles.

\section{Acknowledgements}

This paper draws on research funded by the Planning Exchange Foundation. The authors would like to thank the two anonymous referees as well as Klaus Dodds for their helpful feedback on an earlier draft of the paper. Finally we would like to express our gratitude to those civil servants who gave their time to be interviewed as part of our research.

\section{Notes}

1 Although policymaking for planning is devolved to Wales, primary legislation is currently shared with England. A new planning act is anticipated to be passed by the Welsh Assembly in 2014.

2 There is some debate over the distinctiveness of Scottish planning pre devolution (Rowan-Robinson 1997; cf. Allmendinger 2001).

3 Part of the reform associated with spatial planning has been replacing the 'public inquiries' held before a plan is legally adopted with 'examinations in public'. 


\section{References}

Allmendinger P 2001 The head and the heart. National identity and urban planning in a devolved Scotland International Planning Studies 61 33-54

Allmendinger P 2002 Prospects for a distinctly Scottish planning in a post-sovereign age European Planning Studies 10 359-81

Allmendinger P 2011 New labour and planning: from new right to new left Routledge, Abingdon

BIC 2013 About the British-Irish Council at (www .britishirishcouncil.org/about) Accessed 7 May 2013

Birrell D 2012 Intergovernmental relations and political parties in Northern Ireland British Journal of Politics and International Relations 14 270-84

Bradbury J 2006 'Territory and power' revisited: theorising territorial politics in the United Kingdom after devolution Political Studies 54 559-82

Clifford B 2013 Reform on the frontline: reflections on implementing spatial planning in England, 2004-2008 Planning Practice and Research 28 361-83

Clifford B and Tewdwr-Jones M 2013 The collaborating planner? Practitioners in the neoliberal age Policy Press, Bristol

CLG 2006 Planning policy statement 9: Biodiversity and geological conservation Department for Communities and Local Government, London

CLG 2007a Streamlining local development frameworks: consultation Department for Communities and Local Government, London

CLG 2007b Housing \& Planning Delivery Grant (HPDG): consultation on allocation mechanism Department for Communities and Local Government, London

Cochrane A and Ward K 2012 Guest Editorial: Researching the geographies of policy mobility Environment and Planning A 44 5-12

Danson M, MacLeod G and Mooney G 2012 Guest editorial: Devolution and the shifting political economic geographies of the United Kingdom Environment and Planning C 30 1-9

DoENI 2006 Planning policy statement 15: planning and flood risk Department of the Environment (Northern Ireland), Belfast

DoENI 2008 Development Management Statistics Northern Ireland (www.planningni.gov.uk/index/tools/about-statistics/ about-stats-annual-bulletin-0708.pdf) Accessed 5 May 2013

Dolowitz D 2001 The British child support agency: did American origins bring failure Environment and Planning C 19 373-90

Dolowitz D and Marsh D 2000 Learning from abroad: the role of policy transfer in contemporary policy-making Governance 13 $5-24$

Dolowitz D and Marsh D 2012 The future of policy transfer research Political Studies Review 10 339-45

DRD 2002 Shaping our future: regional development strategy 2025 Department for Regional Development, Belfast

ECLG 2005 Sustainable rural housing: guidelines for planning authorities Government of Ireland, Dublin

ECLG 2007 Development management: guidelines for planning authorities Government of Ireland, Dublin

Evans M 2009 Policy transfer in critical perspective Policy Studies $30243-68$

Freeman R 2012 Reverb: policy making in wave form Environment and Planning A 44 13-20
Goodwin M 2013 Regions, territories and relationality: exploring the regional dimensions of political practice Regional Studies 47 1181-90

Goodwin M, Jones M and Jones R 2005 Devolution, constitutional change and economic development: explaining and understanding the new institutional geographies of the British state Regional Studies 39 421-36

Hazell R 2000 The state of the nations: the first year of devolution in the UK Imprint Academic, Exeter

Hayton K 2002 Scottish development planning: on the brink of change? Planning Practice and Research 17 317-30

Hickey D 2011 Cameron labels planning officials 'enemies of enterprise' (www.planningresource.co.uk/article/1058481/ cameron-labels-planning-officials-enemies-enterprise) Accessed 28 October 2013

Jeffrey C 2009 Devolution in the United Kingdom: problems of a piecemeal approach to constitutional change Publius 39 289-313

Jeffrey C and Wincott D 2006 Devolution in the United Kingdom: statehood and citizenship in transition Publius 36 3-18

Jones R, Goodwin M, Jones R and Simpson G 2004 Devolution, state personnel, and the production of new territories of governance in the United Kingdom Environment and Planning A 36 89-109

Keating M 2009 Rescaling Europe Perspectives on European Politics and Society 10 34-50

Keating M 2012 Intergovernmental relations and innovation: from co-operative to competitive welfare federalism in the UK British Journal of Politics and International Relations 14214 30

Lloyd G 2008 Planning reform in Northern Ireland: independent report to the Minister for the Environment Department of the Environment Northern Ireland, Belfast

MacKinnon D and Shaw J 2010 New state spaces, agency and scale: devolution and the regionalisation of transport governance in Scotland Antipode 42 1226-52

McCann E 2011 Urban policy mobilities and global circuits of knowledge: towards a research agenda Annals of the Association of American Geographers 101 107-30

McCann E and Ward K 2012a Policy assemblages, mobilities and mutations: toward a multidisciplinary conversation Political Studies Review 10 325-32

McCann E and Ward K 2012b Assembling urbanism: following policies and 'studying through' the sites and situations of policy making Environment and Planning A 44 42-51

McEwen N, Swenden W and Bolleyer N 2012 Introduction: Political opposition in a multi-level context British Journal of Politics and International Relations 14 189-97

Morphet J 2010 Effective practice in spatial planning Routledge, London

Morphet J 2013 How Europe shapes British public policy Policy Press, Bristol

Nadin V 2007 The emergence of the spatial planning approach in England Planning, Practice \& Research 22 43-62

Newman P and Thornley A 1996 Urban planning in Europe Routledge, London

Painter J 2008 Cartographic anxiety and the search for regionality Environment and Planning A 40 342-61 
Panizza F and Miorelli R 2013 Taking discourse seriously: discursive institutionalism and post-structuralism discourse theory Political Studies 61 301-18

Parry R 2012 The civil service and intergovernmental relations in the post-devolution UK British Journal of Politics and International Relations 14 285-302

Peck J 2001 Neoliberalising states: thin policies/hard outcomes Progress in Human Geography 25 445-55

Peck J and Theodore N 2010 Mobilizing policy: models, methods and mutations Geoforum 41 169-74

Rowan-Robinson J 1997 The organisation and effectiveness of the Scottish planning system in MacDonald $\mathbf{R}$ and Thomas $\mathbf{H}$ eds Nationality and planning in Scotland and Wales University of Cardiff Press, Cardiff 56-74

Schmidt V 2010 Taking ideas and discourse seriously: explaining change through discursive institutionalism as the fourth 'new institutionalism' European Political Studies Review 2 1-25

Scottish Executive 2004a Scottish planning policy 7: Planning and flooding Scottish Executive Development Department, Edinburgh

Scottish Executive 2004b National planning framework for Scotland Scottish Executive, Edinburgh

Scottish Executive 2005 Scottish planning policy 17: Planning for transport Scottish Executive Development Department, Edinburgh

Scottish Government 2008 National planning framework for Scotland 2: discussion draft Scottish Government, Edinburgh

Shaw J and MacKinnon D 2011 Moving on with 'filling in'? Some thoughts on state restructuring after devolution Area 43 23-30
States of Guernsey 2012 A guide to the States strategic plan States of Guernsey, St Peter Port

Stone D 1999 Learning lessons and transferring policy across time, space and disciplines Politics 19 51-9

Stone D 2001 Learning lessons, policy transfer and the international diffusion of policy ideas CSGR Working Paper Number 69/01, University of Warwick, Warwick

Stone D 2004 Transfer agents and global networks in the 'transnationalization' of policy Journal of European Public Policy 11 545-66

Taylor N 2010 What is this thing called spatial planning? An analysis of the British government's view Town Planning Review 81 193-208

TCPA 2010 National planning framework Town and Country Planning September 2010 1-3

Tewdwr-Jones M 1999 Reconciling competing voices: institutional roles and political expectations in the new governance of planning Town Planning Review 70 417-23

Tewdwr-Jones M 2012 Spatial planning and governance: understanding UK planning Palgrave Macmillan, Basingstoke

TSO 2002 National spatial strategy for Ireland 2002-2020 The Stationary Office, Dublin

Vigar G 2009 Towards an integrated spatial planning? European Planning Studies 17 1571-90

Welsh Government 2012 City Regions Final Report Welsh Government, Cardiff

WAG 2004 People, places futures: the Wales spatial plan Welsh Assembly Government, Cardiff

WAG 2009 Technical advice note 16: Sport, recreation and open space Welsh Assembly Government, Cardiff 